\title{
Formation of aminosilanes in the hot-wire chemical vapor deposition process using $\mathrm{SiH}_{4}-\mathrm{NH}_{3}$ gas mixtures
}

\author{
Brett D. Eustergerling and Yujun Shi* \\ Department of Chemistry, University of Calgary, 2500 University Drive NW, Calgary, Alberta, \\ T2N 1N4, Canada \\ E-mail: shiy@ucalgary.ca
}

Dedicated to Professor Ted Sorensen on the occasion of his $75^{\text {th }}$ birthday

\begin{abstract}
Vacuum ultraviolet laser single photon-ionization coupled with time-of-flight mass spectrometry has been used to detect the gas-phase reaction products from the HWCVD reactor with $\mathrm{SiH}_{4}$ $\mathrm{NH}_{3}$ mixtures with various partial pressure ratios ranging from 1: 1 to $200: 1$ for $\mathrm{NH}_{3}: \mathrm{SiH}_{4}$. The identity of the products depends strongly on the relative amounts of $\mathrm{SiH}_{4}$ and $\mathrm{NH}_{3}$ in the mixture. Low $\mathrm{NH}_{3}$ content favors the production of disilane and trisilane. When the $\mathrm{NH}_{3}$ content is high, the formation of aminosilanes becomes the primary pathway. The production of sufficient amount of $\mathrm{NH}_{2}$ (or $\mathrm{ND}_{2}$ ) radicals is found to play a key role in the competition between the two pathways. The formation of aminosilanes when using mixtures with an ammonia to silane pressure ratio greater than $49: 1$ is confirmed through the use of the isotopomer $\mathrm{ND}_{3}$ in place of $\mathrm{NH}_{3}$ in the gas mixtures. A stepwise amination reaction scheme, initiated by the reaction between the $\mathrm{SiH}_{3}$ and $\mathrm{NH}_{2}$ radicals, is responsible for the formation of aminosilanes. The effect of filament temperature on the formation of aminosilanes and di-/trisilane has also been investigated.
\end{abstract}

Keywords: Aminosilane, hot-wire CVD, catalytic CVD, silicon nitride, vacuum ultraviolet laser single photon ionization

\section{Introduction}

Silicon nitride films have been extensively studied due to their applications as anti-reflection coatings and passivation layers in microelectronic devices. ${ }^{1,2}$ Various chemical vapor deposition (CVD) techniques have been utilized for the deposition of silicon nitride thin films. These include thermal CVD, ${ }^{3}$ plasma-enhanced CVD (PECVD), ${ }^{2,4-6}$ and photo-assisted CVD. ${ }^{7-9}$ Most commonly, mixtures of silane $\left(\mathrm{SiH}_{4}\right)$ and ammonia $\left(\mathrm{NH}_{3}\right)$ serve as the source gas for the 
deposition. In the last two decades, the use of hot-wire CVD (HWCVD), also known as Catalytic CVD (Cat-CVD), to deposit silicon nitride $\left(\mathrm{Si}_{\mathrm{x}} \mathrm{N}_{\mathrm{y}}\right)$ semiconductor thin films has attracted increasing interest ${ }^{1,10}$ because of its ability to grow high quality films at low substrate temperatures while avoiding plasma-induced damages to the films. The technique of HWCVD involves the decomposition of a source gas on a heated metal filament to produce highly reactive radical species, which then react with each other, and with the abundant source gas molecules to generate film-growth precursor species. Ultimately, it is the abundance and identity of these growth precursors that dictates the properties of the resultant thin films. Despite the importance of understanding the gas-phase chemical processes in HWCVD, only recently has there been a focused effort in the literature to develop this understanding. Recent work by Umemoto et al. regarding the deposition chemistry of the $\mathrm{NH}_{3}-\mathrm{SiH}_{4}$ mixtures in the Cat-CVD processes has shown that the silyl $\left(\mathrm{SiH}_{3}\right)$ and amidogen $\left(\mathrm{NH}_{2}\right)$ radicals are the major deposition species for silicon nitride ${ }^{11}$. The suppression effect of $\mathrm{SiH}_{4}$ presence in the mixtures on the $\mathrm{NH}_{3}$ dissociation efficiency has also been demonstrated by several groups ${ }^{12-14}$. This is consistent with the fact that a high gas flow rate ratio of $\mathrm{NH}_{3}$ to $\mathrm{SiH}_{4}$ is typically needed under practical deposition conditions for silicon nitride films. However, very little is known about the formation of compounds containing direct silicon-nitrogen bond in the gas-phase in the HWCVD processes using $\mathrm{NH}_{3}-\mathrm{SiH}_{4}$ mixtures. In our study of examining the gas-phase chemical products of an $\mathrm{NH}_{3}-$ $\mathrm{SiH}_{4}$ mixture with an $\mathrm{NH}_{3}$ to $\mathrm{SiH}_{4}$ partial pressure ratio of $100: 1^{15}$, the notable different intensity ratio of the peak at $\mathrm{m} / \mathrm{z}=92$ to that at $\mathrm{m} / \mathrm{z}=62$ from that assumed by pure $\mathrm{SiH}_{4}$ samples and the observation of a peak at $\mathrm{m} / \mathrm{z}=76$ has led us to conclude that tetraaminosilane, $\mathrm{Si}\left(\mathrm{NH}_{2}\right)_{4}$, is formed in the process with this mixture.

Aminosilane species have been proposed in previous studies to be very important filmgrowth precursors in $\mathrm{PECVD}^{4}$ and photo-assisted CVD using excimer laser radiation at $193 \mathrm{~nm}^{7}$. Efforts have also been made to elucidate the mechanism of aminosilane formation in various CVD systems using mixtures of $\mathrm{SiH}_{4}$ and $\mathrm{NH}_{3}$. Theoretical calculation considering gas-phase reactions between $\mathrm{SiH}_{4}$ and $\mathrm{NH}_{3}$ revealed that silylamine, $\mathrm{H}_{2} \mathrm{~N}-\mathrm{SiH}_{3}$, the simplest aminosilane species, is the most favorable reaction product both thermodynamically and kinetically. ${ }^{16}$ Koseki et al. ${ }^{17}$ and $\mathrm{O}$ 'Neal et al. ${ }^{18}$ have shown that the insertion of silylene into $\mathrm{N}-\mathrm{H}$ bond of $\mathrm{NH}_{3}$ to form silylamine plays an important role in the pyrolysis process of the $\mathrm{NH}_{3}-\mathrm{SiH}_{4}$ mixture. In their study of silicon nitride film formation in a photo-assisted CVD involving the $\mathrm{NH}_{3}-\mathrm{SiH}_{4}$ mixture with a $185 \mathrm{~nm}$ radiation from a $\mathrm{Hg}$ lamp, Yoshimoto et al. ${ }^{9}$ suggested that $\mathrm{SiH}_{3}$ and $\mathrm{NH}_{2}$ species, produced by the decomposition of $\mathrm{NH}_{3}$ and $\mathrm{SiH}_{4}$, reacted to form $\mathrm{SiNH}_{5}$. Considering the fact that the formation of $\mathrm{H}_{2} \mathrm{~N}-\mathrm{SiH}_{3}$ was shown to be more thermodynamically and kinetically favourable compared to that of $\mathrm{H}_{3} \mathrm{~N}-\mathrm{SiH}_{2}{ }^{16}$, it is reasonable to assign the identity of the $\mathrm{SiNH}_{5}$ species which Yoshimoto observed to silylamine. Further evidence of the formation of silylamine and other silyated amines in the mercury-photosensitized reactions of $\mathrm{SiH}_{4}$ and $\mathrm{NH}_{3}$ was provided by $\mathrm{Wu}^{8}{ }^{8}$

In 1990, Beach and Jasinski ${ }^{7}$ reported a detailed study of the photochemistry of $\mathrm{NH}_{3}-\mathrm{SiH}_{4}$ mixtures induced by a $193 \mathrm{~nm}$ excimer laser radiation. Signals from all possible aminosilanes, 
$\mathrm{SiH}_{\mathrm{x}}\left(\mathrm{NH}_{2}\right)_{4-\mathrm{x}}(\mathrm{x}=0-3)$, were observed using mass spectrometry. It was found that increasing the amount of ammonia in the gas mixture favored the production of aminosilanes over disilane and trisilane. Their proposed mechanism for the formation of aminosilanes constitutes the stepwise amination of $\mathrm{SiH}_{3-\mathrm{x}}\left(\mathrm{NH}_{2}\right)_{\mathrm{x}}(\mathrm{x}=0-3)$ as shown in Eqns. (1) to (3).

$$
\begin{aligned}
& \mathrm{NH}_{2}+\mathrm{SiH}_{3-\mathrm{x}}\left(\mathrm{NH}_{2}\right)_{\mathrm{x}} \rightarrow \mathrm{H}+\mathrm{SiH}_{2-\mathrm{x}}\left(\mathrm{NH}_{2}\right)_{1+\mathrm{x}}(\mathrm{x}=0-2) \\
& \mathrm{SiH}_{2-\mathrm{x}}\left(\mathrm{NH}_{2}\right)_{1+\mathrm{x}}+\mathrm{H} \rightarrow \mathrm{SiH}_{3-\mathrm{x}}\left(\mathrm{NH}_{2}\right)_{1+\mathrm{x}}(\mathrm{x}=0-2) \\
& \mathrm{NH}_{2}+\mathrm{Si}\left(\mathrm{NH}_{2}\right)_{3} \rightarrow \mathrm{Si}\left(\mathrm{NH}_{2}\right)_{4}
\end{aligned}
$$

The above stepwise amination mechanism was supported by the work on the deposition chemistry for silicon nitride films from the $\mathrm{NH}_{3}-\mathrm{SiH}_{4}$ plasma reported by Smith et al. ${ }^{4}$ in the same year. The gas-phase plasma chemistry was found to depend strongly on the radio-frequency (RF) power used to form the plasma. At low RF power, the dominant reaction pathway was the formation of disilane, which was attributed to the reaction of silyl radicals with each other and with silane, while ammonia acting as an inert diluent. At higher RF powers, the pathway leading to aminosilane formation became dominant. The existence of different growth regimes from $\mathrm{NH}_{3}-\mathrm{SiH}_{4}$ plasma deposition was later confirmed in an optical emission spectroscopic investigation $^{5}$. Theoretical work has also been conducted to investigate the formation of aminosilanes. Kushner ${ }^{19}$ showed that $\mathrm{NH}_{2}$ is unreactive toward $\mathrm{SiH}_{4}$, which supports the results from Beach and Jasinski, as well as their proposed mechanism.

Though plasma CVD chemistry with $\mathrm{NH}_{3}-\mathrm{SiH}_{4}$ mixtures has been well studied, it is unclear if the same chemistry and mechanisms are taking place in the HWCVD process. Aminosilanes have been identified only recently in HWCVD, ${ }^{15}$ and no detailed investigation into their formation mechanism has been presented. In this work, we present a more thorough discussion of the evidence in favor of the formation of aminosilane species in the HWCVD process using various $\mathrm{SiH}_{4}$ and $\mathrm{NH}_{3}$ gas mixtures with different partial pressure ratios to determine the experimental condition that favor their production. Results of our efforts to identify the mechanism of the aminosilane formation using deuterated ammonia $\left(\mathrm{ND}_{3}\right)$ are presented. Focus is also given on the issue if any of the radical products originating from $\mathrm{NH}_{3}$ decomposition contribute to the formation of disilane and trisilane.

\section{Experimental Details}

Our previous experiments on detecting the reaction products from using $\mathrm{NH}_{3}-\mathrm{SiH}_{4}$ mixtures in a HWCVD reactor employed a time-of-flight mass spectrometer with an ionization source of coexisting laser induced electron impact ionization (LIEI) and a $118 \mathrm{~nm}$ vacuum ultraviolet (VUV) laser single-photon ionization (SPI), ${ }^{14,15}$ i.e., the dual LIEI/SPI source. It has been shown that species with an ionization potential (I. P.) below $10.5 \mathrm{eV}$, such as $\mathrm{Si}_{2} \mathrm{H}_{6}$ and $\mathrm{Si}_{3} \mathrm{H}_{8}$, exhibit stronger peaks in the mass spectra recorded under pure VUV SPI mode, whereas the signals from 
those with I.P. above $10.5 \mathrm{eV}$, e.g., $\mathrm{H}_{2}$ and $\mathrm{N}_{2}$, are enhanced with the dual LIEI/SPI mode. In this work, the signals from $\mathrm{Si}_{2} \mathrm{H}_{6}{ }^{+}, \mathrm{Si}_{3} \mathrm{H}_{8}{ }^{+}$and $\mathrm{Si}\left(\mathrm{NH}_{2}\right)_{4}{ }^{+}$are of most interest to us. Although the I. P. of $\mathrm{Si}\left(\mathrm{NH}_{2}\right)_{4}$ is unknown, our experiment has shown that the signal from $\mathrm{Si}\left(\mathrm{NH}_{2}\right)_{4}{ }^{+}$has been enhanced by switching from the dual LIEI/SPI source to the pure SPI source, suggesting that its I. P. is below $10.5 \mathrm{eV}$. Therefore, for enhanced signals of $\mathrm{Si}_{2} \mathrm{H}_{6}{ }^{+}, \mathrm{Si}_{3} \mathrm{H}_{8}{ }^{+}$and $\mathrm{Si}\left(\mathrm{NH}_{2}\right)_{4}{ }^{+}$, the pure VUV SPI source coupled with TOF MS is employed in this work for the examination of aminosilane and disilane/trisilane formation.

The details of the experimental apparatus to record the VUV laser SPI / TOF mass spectra of the reaction products from a HWCVD reactor have been reported in our previous work. ${ }^{20,}{ }^{21}$ In brief, a HWCVD reactor, housing a heated tungsten filament, is incorporated by way of a 0.15 $\mathrm{mm}$ diameter pinhole into a high-vacuum ionization chamber for the TOF mass spectrometer (R. M. Jordan Inc.). The total pressures in the reactor are maintained at $\sim 12$ Torr using a mass flow controller (MFC), while those in the ionization chamber are $\sim 4.0 \times 10^{-6}$ Torr under working conditions. Gas-phase reaction products are continuously sampled through the pinhole, forming an effusive molecular beam. Sample molecules are ionized by a VUV photon of $10.5 \mathrm{eV}$ (118 $\mathrm{nm}$ ) in a single-photon ionization process. The $118 \mathrm{~nm}$ laser radiation was generated by frequency tripling the $355 \mathrm{~nm}$ UV output from an Nd:YAG laser (Spectra Physics, Lab 170-10). A lithium fluoride (LiF) lens was used to focus the $118 \mathrm{~nm}$ VUV light at the center of the ion source in the TOF MS. Ions extracted and dispersed into the 1-meter-long flight tube are detected by a microchannel plate (MCP) detector. Signals from the MCP detector are averaged over 512 laser shots before being saved to a computer for analysis. Mass spectra were collected for every minute over a ten-minute time span after turning on the filament. Filament temperatures ranged from $1500-2000^{\circ} \mathrm{C}$ and were monitored by a two-color pyrometer (Chino Works).

The $\mathrm{NH}_{3}-\mathrm{SiH}_{4}$ source gas mixtures under study were prepared using pure $\mathrm{NH}_{3}(99.999 \%$, BOC Gases), 1\% $\mathrm{SiH}_{4}$ in $\mathrm{He}$ (BOC Gases), and ultra high purity He (99.995\%, Praxair). Mixtures with various partial pressure ratios were prepared in a $2.25 \mathrm{~L}$ stainless steel sample cylinder before being introduced into the HWCVD reactor. The composition of the $\mathrm{NH}_{3} / \mathrm{SiH}_{4}$ gas mixtures studied in this work is listed in Table 1. To develop a more thorough understanding of the formation of aminosilane and disilane/trisilane, the isotopomer $\mathrm{ND}_{3}(99.99 \%$, Spectra Gases) was used to replace $\mathrm{NH}_{3}$, and the same experiments were conducted using the same compositions as listed in Table 1. 
Table 1. Composition of the $\mathrm{NH}_{3} / \mathrm{SiH}_{4} / \mathrm{He}$ mixtures studied in this work

\begin{tabular}{lll}
\hline $\begin{array}{l}\text { Mixtures } \\
\left(\mathrm{P}\left(\mathrm{NH}_{3}\right): \mathrm{P}\left(\mathrm{SiH}_{4}\right)\right)\end{array}$ & $\begin{array}{l}\mathrm{P}\left(\mathrm{NH}_{3}\right) \\
(\text { Torr })\end{array}$ & $\begin{array}{l}\mathrm{P}\left(\mathrm{SiH}_{4}\right) \\
(\text { Torr })\end{array}$ \\
\hline $200: 1$ & 660 & 3.3 \\
$100: 1$ & 1000 & 10 \\
$49: 1$ & 660 & 13.5 \\
$23: 1$ & 380 & 16.3 \\
$1: 1$ & 20 & 20 \\
\hline
\end{tabular}

${ }^{a}$ All mixtures are balanced with He to a total pressure of 3 atm.

\section{Results and Discussion}

The gas-phase reaction chemistry of $\mathrm{SiH}_{4}$ in the HWCVD processes has been well studied. ${ }^{22,23}$ $\mathrm{The}_{\mathrm{SiH}}$ molecule decomposes on the hot tungsten filament to $\mathrm{Si}$ and $\mathrm{H}$ atoms, which then react with the ambient silane molecules to form the final mix of depositing precursors such as $\mathrm{SiH}_{3}$ and $\mathrm{Si}_{2} \mathrm{H}_{2 \mathrm{y}}(\mathrm{y}=1-3) .{ }^{24-27}$ Our previous work has shown that the principal gas-phase reaction products when using $\mathrm{SiH}_{4}$ as a source gas in a HWCVD reactor are $\mathrm{Si}_{2} \mathrm{H}_{6}, \mathrm{Si}_{3} \mathrm{H}_{8}$, and $\mathrm{H}_{2}$. ${ }^{14}, 15$ The intensity ratio of the peaks from disilane to trisilane was found to be $2.9: 1$. This is consistent with the work reported by Nakamura et al., ${ }^{28}$ who proposed a mechanism for the formation of the higher-order silanes, initiated by the recombination reactions between $\mathrm{SiH}_{3}$ radicals. Therefore, the detection of $\mathrm{Si}_{2} \mathrm{H}_{6}, \mathrm{Si}_{3} \mathrm{H}_{8}$ and $\mathrm{H}_{2}$ in our work using $\mathrm{SiH}_{4}$ in the HWCVD reactor strongly suggests that $\mathrm{SiH}_{3}$ radicals are being produced in the process. Our examination of the reaction chemistry of $\mathrm{NH}_{3}$ in the HWCVD process has found that the major gas-phase products correspond to hydrogen and nitrogen. ${ }^{14,15}$ The deposition chemistry of ammonia in the HWCVD process has been well characterized by Umemoto et al. ${ }^{29}$ They have identified $\mathrm{H}$ and $\mathrm{NH}_{2}$ radicals as the primary decomposition products of $\mathrm{NH}_{3}$ on the hot $\mathrm{W}$ filaments. Signals from $\mathrm{H}_{2}$ and $\mathrm{N}_{2}$ were also detected using mass spectrometry. It was proposed that the $\mathrm{H}_{2}$ and $\mathrm{N}_{2}$ are produced mainly as a result of chamber wall reactions involving the $\mathrm{NH}_{2}$ radicals, with minor contributions from the gas-phase reactions also originating from the $\mathrm{NH}_{2}$ radicals. The detection of the $\mathrm{N}_{2}$ and $\mathrm{H}_{2}$ species in our work indicates that $\mathrm{NH}_{2}$ radicals are being formed in our system.

To investigate the gas-phase reaction chemistry of the mixtures of $\mathrm{SiH}_{4}$ and $\mathrm{NH}_{3}$ in the HWCVD processes, mixtures with the partial pressure ratio of $\mathrm{NH}_{3}$ to $\mathrm{SiH}_{4}$ ranging from $1: 1$ to 200 : 1 were prepared and the products from using each mixture in the HWCVD reactor were detected using the VUV SPI TOF mass spectrometer. Figure 1 shows the mass spectra from 
using different $\mathrm{NH}_{3}-\mathrm{SiH}_{4}$ mixtures in the HWCVD reactor at a filament temperature of $1500{ }^{\circ} \mathrm{C}$. For comparison, the mass spectrum of $1 \% \mathrm{SiH}_{4}$ in He mixture is also shown in Figure 1.
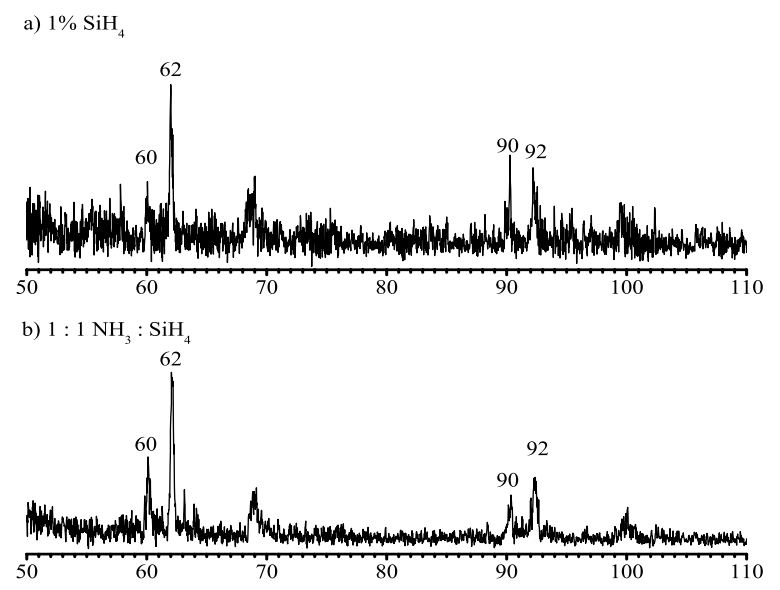

c) $23: 1 \mathrm{NH}_{3}: \mathrm{SiH}_{4}$

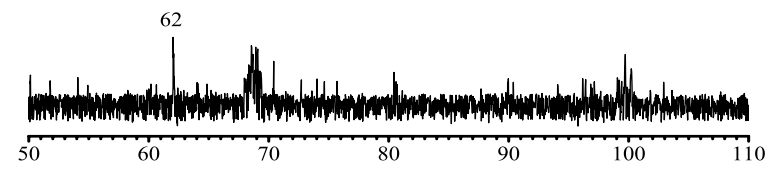

d) $49: 1 \mathrm{NH}_{3}: \mathrm{SiH}_{4}$

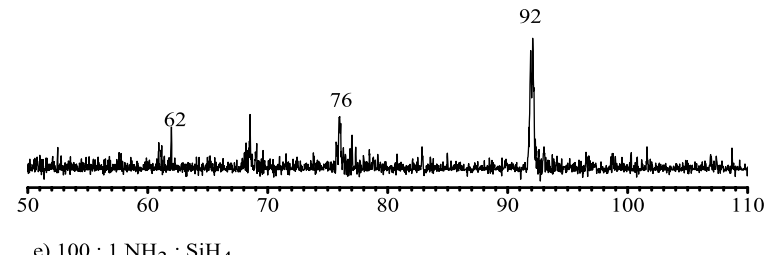

e) $100: 1 \mathrm{NH}_{3}: \mathrm{SiH}_{4}$

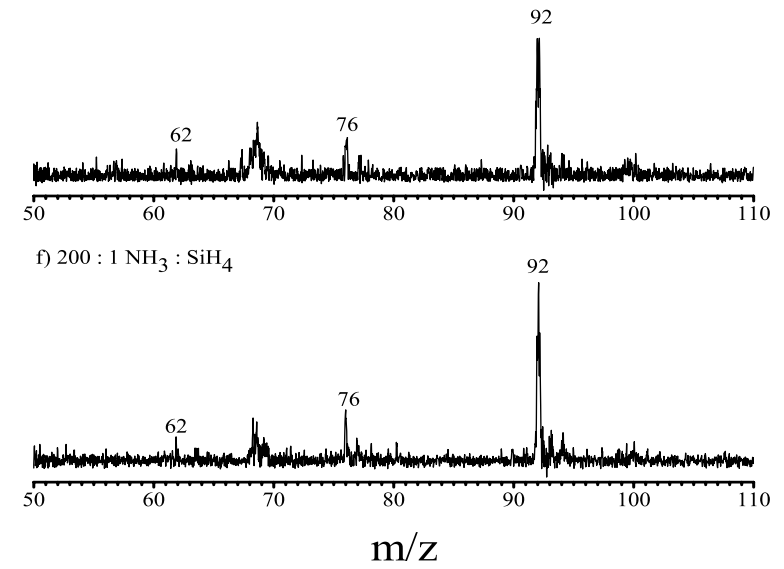

Figure 1. The $118 \mathrm{~nm}$ VUV laser SPI / TOF mass spectra of 12 Torr of (a) 1\% $\mathrm{SiH}_{4} / \mathrm{He}$; (b) 1 : 1; (c) $23: 1$; (d) $49: 1$; (e) $100: 1$; and (f) $200: 1 \mathrm{NH}_{3}: \mathrm{SiH}_{4}$ in He mixture in the mass region of $50-110 \mathrm{amu}$ at a filament temperature of $1500{ }^{\circ} \mathrm{C}$. 
For the $1: 1 \mathrm{NH}_{3}: \mathrm{SiH}_{4}$ mixture, the production of disilane $(\mathrm{m} / \mathrm{z}=62)$ and trisilane $(\mathrm{m} / \mathrm{z}=$ 92) was unaffected by the addition of $\mathrm{NH}_{3}$. The intensity ratio of the peak at $\mathrm{m} / \mathrm{z}=62$ to that at $\mathrm{m} / \mathrm{z}=92$ was nearly identical to the ratio observed using only $\mathrm{SiH}_{4}$. Signals in the mass region above $50 \mathrm{amu}$ from the $23: 1 \mathrm{NH}_{3}: \mathrm{SiH}_{4}$ mixture were generally very weak, however, the signals at $\mathrm{m} / \mathrm{z}=62$ still dominated and that at $\mathrm{m} / \mathrm{z}=92$ was not visible. Increasing the amount of $\mathrm{NH}_{3}$ in the mixture further caused a significant change in the relative intensities of the two mass peaks at $\mathrm{m} / \mathrm{z}=62$ and 92 in the spectra. For the $49: 1 \mathrm{NH}_{3}: \mathrm{SiH}_{4}$ mixture, the peak at $\mathrm{m} / \mathrm{z}=92$ became stronger than that at $\mathrm{m} / \mathrm{z}=62$, as shown in Figure 1d). At the same time, a peak at $\mathrm{m} / \mathrm{z}=$ 76 was observed with this mixture. The behavior from the more $\mathrm{NH}_{3}$-enriched mixtures, i.e., the $100: 1$ and $200: 1 \mathrm{NH}_{3}: \mathrm{SiH}_{4}$ mixtures, was very similar to those of the $49: 1 \mathrm{NH}_{3}: \mathrm{SiH}_{4}$ mixture. As previously described, the study of $1 \% \mathrm{SiH}_{4}$ in He mixture revealed that the peak at $\mathrm{m} / \mathrm{z}=62\left(\mathrm{Si}_{2} \mathrm{H}_{6}{ }^{+}\right)$was always stronger than the peak at $\mathrm{m} / \mathrm{z}=92\left(\mathrm{Si}_{3} \mathrm{H}_{8}{ }^{+}\right)$. When considering the characteristic ratio of the peak at $\mathrm{m} / \mathrm{z}=62$ to that at $\mathrm{m} / \mathrm{z}=92$ of $2.9: 1$ for $1 \% \mathrm{SiH}_{4}$ and the weak intensities of the peak at $\mathrm{m} / \mathrm{z}=62$ for the $49: 1,100: 1$ and $200: 1 \mathrm{NH}_{3}: \mathrm{SiH}_{4}$ mixtures, it is clear that the contribution of trisilane to the $m / z=92$ peak intensities in Figures $1 \mathrm{~d}$ ) $-1 \mathrm{f}$ ) is negligible. This suggests that the majority of the intensity at $m / z=92$ in Figures $1 d$ ) - 1f) must originate from a new species, which was proposed to be tetraaminosilane, $\mathrm{Si}\left(\mathrm{NH}_{2}\right)_{4}$, in our previous work. ${ }^{15}$ The peak at $\mathrm{m} / \mathrm{z}=76$ was not consistently observed in our previous work due to the weak nature of this signal from using the dual SPI/LIEI source. When using the pure SPI source in this work, the signal intensity for the peaks at $\mathrm{m} / \mathrm{z}=92$ and 76 is enhanced. It is found that the $\mathrm{m} / \mathrm{z}=76$ peak almost always accompanies the observation of that at $\mathrm{m} / \mathrm{z}=92$. The intensity ratio for the peak at $\mathrm{m} / \mathrm{z}=92$ to the one at $\mathrm{m} / \mathrm{z}=76$ ranges from 2.4 to 8.7 , depending on the source mixture composition and filament temperature. Both Smith et al. ${ }^{4}$ and Beach et al. ${ }^{7}$ observed the peak at $\mathrm{m} / \mathrm{z}=76$ in their work, which was assigned to be $\mathrm{Si}\left(\mathrm{NH}_{2}\right)_{3}{ }^{+}$. Smith et al. attributed this peak to be from either triaminosilane $\left(\mathrm{SiH}\left(\mathrm{NH}_{2}\right)_{3}{ }^{+}\right)$losing a $\mathrm{H}$ atom or tetraaminosilane $\left(\mathrm{Si}\left(\mathrm{NH}_{2}\right)_{4}{ }^{+}\right)$losing an $\mathrm{NH}_{2}$ fragment, whereas Beach et al. assigned it to be the M-1 peak from the triaminosilane parent ion. When examining the intensity of the $\mathrm{m} / \mathrm{z}=77$ peak observed in this work, it was found to vary from $15.5 \%$ to $119 \%$ of the intensity of the $\mathrm{m} / \mathrm{z}=76$ peak. This is much larger than the $6.2 \%$ intensity expected from the $(\mathrm{M}+1)$ isotope contribution from the $\mathrm{m} / \mathrm{z}=76$ peak. Therefore, triaminosilane, $\mathrm{SiH}\left(\mathrm{NH}_{2}\right)_{3}{ }^{+}$, might contribute to the peak intensity at $\mathrm{m} / \mathrm{z}=77$ observed in this work and the $\mathrm{Si}\left(\mathrm{NH}_{2}\right)_{3}{ }^{+}$peak observed could be the fragment ion of both triaminosilane and tetraaminosilane parent ions.

To confirm the assignments of $\mathrm{Si}\left(\mathrm{NH}_{2}\right)_{4}{ }^{+}$and $\mathrm{Si}\left(\mathrm{NH}_{2}\right)_{3}{ }^{+}$, respectively, to the peak at $\mathrm{m} / \mathrm{z}=92$ and 76 for the $49: 1,100: 1$ and $200: 1 \mathrm{NH}_{3}: \mathrm{SiH}_{4}$ mixtures, the same experiments were repeated using an isotropically labelled source gas, $\mathrm{ND}_{3}$, in place of $\mathrm{NH}_{3}$ in the gas mixtures. Figure 2 shows the mass spectra in the mass region of $50-110$ amu for a $100: 1$ mixture of $\mathrm{ND}_{3}$ : $\mathrm{SiH}_{4}$ and a $100: 1 \mathrm{NH}_{3}: \mathrm{SiH}_{4}$ mixture, respectively, at a filament temperature of $1800{ }^{\circ} \mathrm{C}$. 

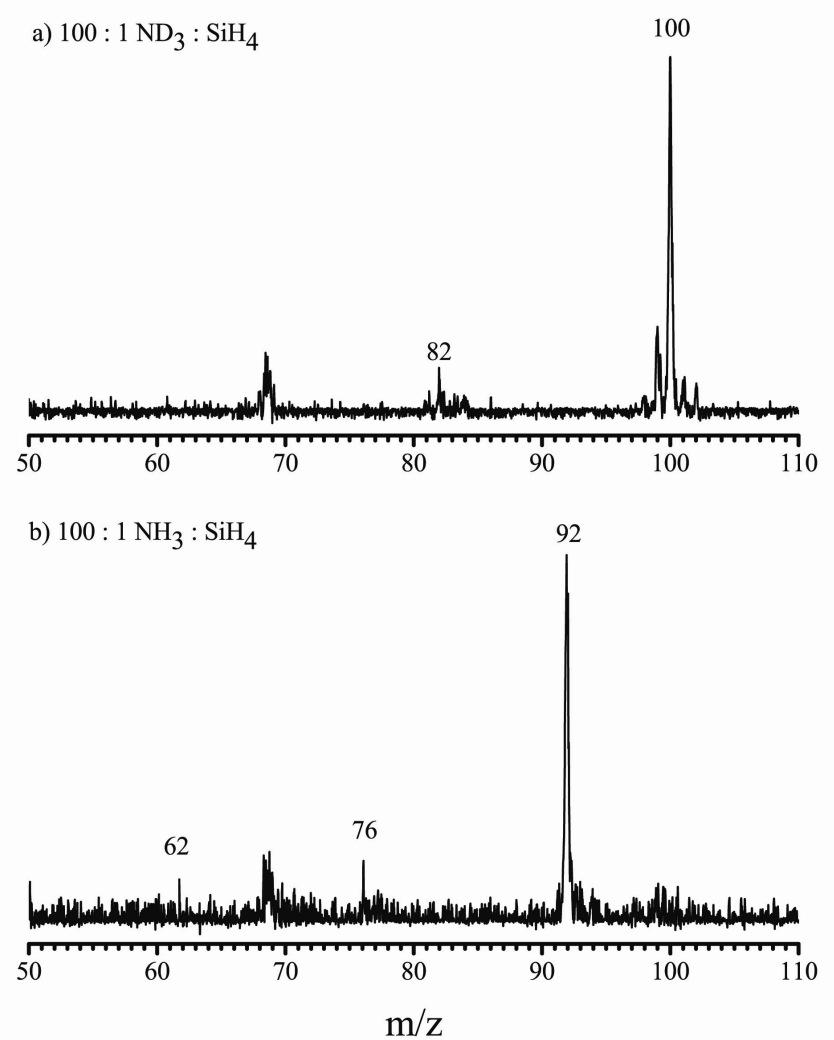

Figure 2. The $118 \mathrm{~nm}$ VUV laser SPI / TOF mass spectra of 12 Torr of (a) $100: 1 \mathrm{ND}_{3}: \mathrm{SiH}_{4}$; and (b) $100: 1 \mathrm{NH}_{3}: \mathrm{SiH}_{4}$ in He mixture in the mass region of $50-110 \mathrm{amu}$ at a filament temperature of $1800^{\circ} \mathrm{C}$.

The $\mathrm{Si}\left(\mathrm{NH}_{2}\right)_{4}{ }^{+}$peak at $\mathrm{m} / \mathrm{z}=92$ is completely absent in the spectrum obtained using $\mathrm{ND}_{3}$. At the same time, by using $\mathrm{ND}_{3}$, the peak at $\mathrm{m} / \mathrm{z}=100$ demonstrates a strong increase in intensity when the filament is turned on. Clearly, the $\mathrm{m} / \mathrm{z}=92$ peak is shifted to $\mathrm{m} / \mathrm{z}=100$ when $\mathrm{NH}_{3}$ is replaced by $\mathrm{ND}_{3}$. This corresponds to the identification of the peak at $\mathrm{m} / \mathrm{z}=100$ as $\mathrm{Si}\left(\mathrm{ND}_{2}\right)_{4}{ }^{+}$, which confirms our assignment of the $\mathrm{m} / \mathrm{z}=92$ peak as $\mathrm{Si}\left(\mathrm{NH}_{2}\right)_{4}{ }^{+}$. Simultaneously, the $\mathrm{m} / \mathrm{z}=76$ peak observed with $\mathrm{NH}_{3}$ shifts to $\mathrm{m} / \mathrm{z}=82$ when $\mathrm{ND}_{3}$ is used instead, indicating that the peak at $\mathrm{m} / \mathrm{z}=82$ is from $\mathrm{Si}\left(\mathrm{ND}_{2}\right)_{3}{ }^{+}$, confirming our assignment of the $\mathrm{m} / \mathrm{z}=76$ peak with $\mathrm{NH}_{3}$ to $\mathrm{Si}\left(\mathrm{NH}_{2}\right)_{3}{ }^{+}$. It is noted that in the mass spectra shown in Figure $2 \mathrm{a}$ ) with the $100: 1 \mathrm{ND}_{3}: \mathrm{SiH}_{4}$ mixture, peaks with mass separation of $1 \mathrm{amu}$ from the two main peaks at $\mathrm{m} / \mathrm{z}=82$ and 100 were also observed, but relatively weakly, indicating some isotope scrambling for the two peaks. This is attributed to the $\mathrm{ND}_{2} \mathrm{H}$ isotope impurities in the $\mathrm{ND}_{3}$ source gas, which was confirmed from the existence of a mass peak at $\mathrm{m} / \mathrm{z}=19$ in our room-temperature mass spectrum of the $50 \%$ $\mathrm{ND}_{3}$ gas sample. If the parent triaminosilane peak, $\mathrm{SiH}\left(\mathrm{NH}_{2}\right)_{3}{ }^{+}$, contributed to the peak intensity at $\mathrm{m} / \mathrm{z}=77$, the peak should be shifted to $\mathrm{m} / \mathrm{z}=83$ or 84 upon replacing the $\mathrm{NH}_{3}$ with $\mathrm{ND}_{3}$ isotopomer. These two mass peaks are the isotope peaks of the $\operatorname{Si}\left(\mathrm{ND}_{2}\right)_{3}{ }^{+}$at $\mathrm{m} / \mathrm{z}=82$. However, the intensities of the $\mathrm{m} / \mathrm{z}=83$ and 84 peaks were found to be $19 \%-83 \%$ and $18 \%-118 \%$, 
respectively, of the intensity of the $\mathrm{m} / \mathrm{z}=82$ peak. This suggests that triaminosilane is likely formed in the system. Our experiment using $\mathrm{ND}_{3}$ to replace $\mathrm{NH}_{3}$ in the $100: 1 \mathrm{NH}_{3}: \mathrm{SiH}_{4}$ mixture clearly demonstrates that the peaks at $\mathrm{m} / \mathrm{z}=76$ and 92 originate from the $\mathrm{Si}\left(\mathrm{NH}_{2}\right)_{3}{ }^{+}$and $\mathrm{Si}\left(\mathrm{NH}_{2}\right)_{4}{ }^{+}$species, and more importantly, all the $\mathrm{H}$ atoms in the two species come from the $\mathrm{NH}_{3}$ component in the mixture. This is consistent with the stepwise amination mechanism proposed by both Beach et $a l^{7}$ and Smith et $a l{ }^{4}$ As represented by Eqn. (1) with $\mathrm{x}=0$, the reaction between $\mathrm{SiH}_{3}$ and $\mathrm{NH}_{2}$ to form $\mathrm{SiH}_{2} \mathrm{NH}_{2}$ constitutes the first step in the stepwise mechanism. The discussions at the beginning of this section have clarified that the two radical reactants in this first step, i.e., $\mathrm{NH}_{2}$ and $\mathrm{SiH}_{3}$, are being produced in the HWCVD reactor using the two components in the mixture separately. Therefore, the formation of tetraaminosilane in our HWCVD reactor with the $\mathrm{NH}_{3} / \mathrm{SiH}_{4}$ mixtures is possible through the stepwise amination mechanism represented by Eqns. (1) - (3).

In the theoretical simulations of the gas-phase processes in the rare gas-silane-ammonia plasma system, Kushner showed that the production of $\mathrm{NH}_{2}$ in sufficient densities from $\mathrm{NH}_{3}$, Eqn. (4), is the rate-limiting step in producing the aminosilanes. ${ }^{19}$

$$
\mathrm{NH}_{3} \rightarrow \mathrm{NH}_{2}+\mathrm{H}
$$

Results from reports by several groups ${ }^{2,5,6}$ have provided clear support to the argument that $\mathrm{NH}_{2}$ radical abundance is the key determinant in the formation of tetraaminosilane in the $\mathrm{NH}_{3}-\mathrm{SiH}_{4}$ plasma systems. This also explains the clear trend in the change of the intensity ratios of the peak at $\mathrm{m} / \mathrm{z}=62$ to that at $\mathrm{m} / \mathrm{z}=92$ for the mixtures of $200: 1,100: 1,49: 1,23: 1$ and $1: 1$ $\mathrm{NH}_{3}: \mathrm{SiH}_{4}$ content, as illustrated in Figure 1. When ammonia is present in equal proportion to silane, aminosilane production is not observed and the intensity ratio of the peak at $\mathrm{m} / \mathrm{z}=62$ to that at $\mathrm{m} / \mathrm{z}=92$ is virtually identical to that observed when ammonia is absent. This indicates that the formation of disilane and trisilane is still predominant in the $1: 1 \mathrm{NH}_{3}: \mathrm{SiH}_{4}$ mixture. When the ammonia content is 49 times that of the silane content in the mixture, the production of tetraaminosilane becomes so significant that the peak at $\mathrm{m} / \mathrm{z}=92$ is actually much stronger than the peak at $\mathrm{m} / \mathrm{z}=62$. The production of tetraaminosilane is more pronounced as the proportion of ammonia increases, as evidenced by the increase in the intensity ratio of the peak at $\mathrm{m} / \mathrm{z}=92$ to that at $\mathrm{m} / \mathrm{z}=62$ in the $49: 1$ to $200: 1 \mathrm{NH}_{3}: \mathrm{SiH}_{4}$ mixtures. These results are consistent with the proposed formation mechanism, whereby production of $\mathrm{NH}_{2}$ radicals from $\mathrm{NH}_{3}$ decomposition acts as the limiting factor in aminosilane formation. As shown in our previous work regarding the interplay of the $\mathrm{NH}_{3}$ and $\mathrm{SiH}_{4}$ components in the gas-phase reaction chemistry in HWCVD, by raising the amount of $\mathrm{NH}_{3}$ in the mixtures, the decomposition efficiency of $\mathrm{NH}_{3}$ increases ${ }^{14}$. This, in turn, results in the production of more $\mathrm{NH}_{2}$ radicals and consequently more tetraaminosilane will form. Beach and Jasinski noted in their work of photochemistry from the $193 \mathrm{~nm}$ laser photolysis of $\mathrm{SiH}_{4}-\mathrm{NH}_{3}$ mixtures that increasing the ratio of ammonia to silane in the mixture favors production of the higher aminosilanes at the expense of disilane and trisilane formation. They observed that disilane production dominates the 
product spectra for the $1: 1$ and $10: 1 \mathrm{NH}_{3}: \mathrm{SiH}_{4}$ mixtures, and its formation was not quenched even at a $49: 1 \mathrm{NH}_{3}: \mathrm{SiH}_{4}$ ratio. This is good agreement with our observations; although not dominant, the disilane signals were present with a mixture having a $49: 1 \mathrm{NH}_{3}: \mathrm{SiH}_{4}$ ratio, as shown in Figure 1d). In our experiments, the disilane signals were observable even at an ammonia to silane ratio of $200: 1$. It appears that there is an active competition between the two reaction pathways. Formation of disilane and trisilane dominates unless there is a great excess of $\mathrm{NH}_{3}$ molecules, at which time aminosilane production becomes the dominant pathway.

Figure 3 shows the mass spectra from using different $\mathrm{ND}_{3}-\mathrm{SiH}_{4}$ mixtures in the HWCVD reactor at a filament temperature of $1500{ }^{\circ} \mathrm{C}$.

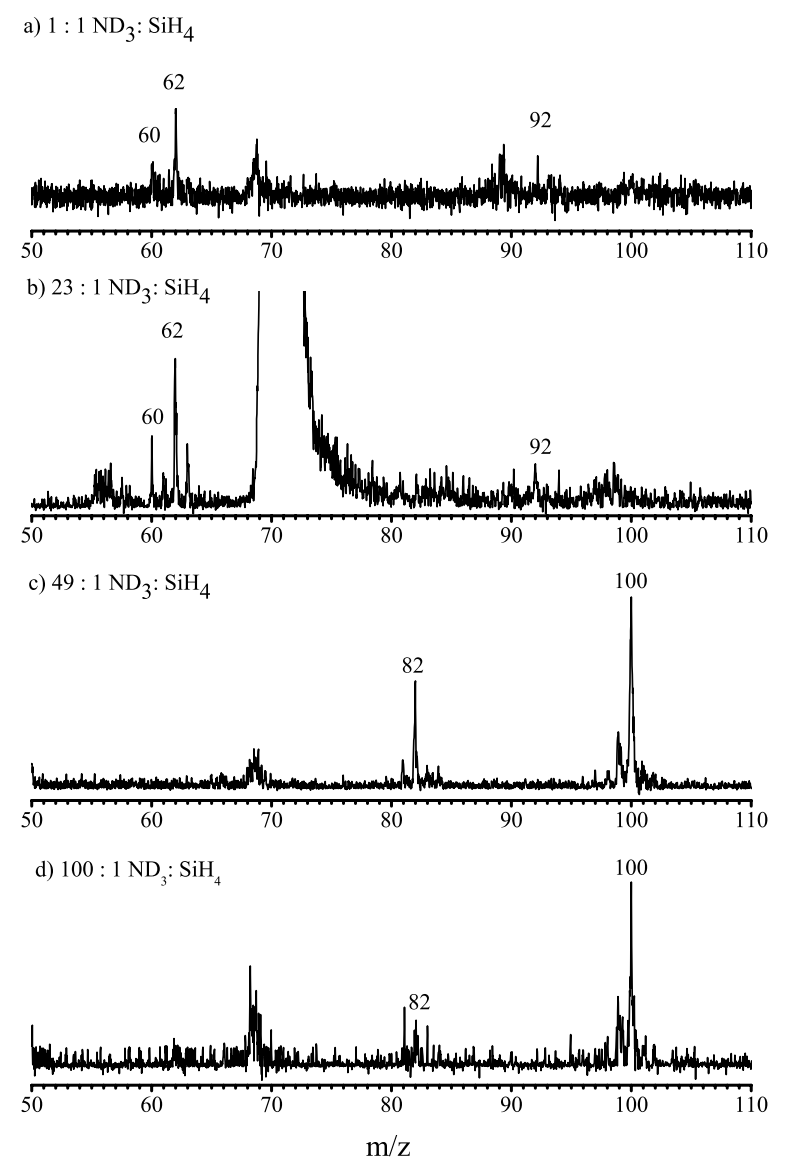

Figure 3. The $118 \mathrm{~nm}$ VUV laser SPI / TOF mass spectra of 12 Torr of (a) $1: 1$; (c) $23: 1 \mathrm{ND}_{3}$ : $\mathrm{SiH}_{4}$; (d) $49: 1$; and (e) $100: 1 \mathrm{ND}_{3}: \mathrm{SiH}_{4}$ in He mixture in the mass region of $50-110$ amu at a filament temperature of $1500{ }^{\circ} \mathrm{C}$.

Clearly, the mixtures with lower $\mathrm{ND}_{3}$ content, such as those of the $1: 1$ and $23: 1 \mathrm{ND}_{3}: \mathrm{SiH}_{4}$ mixtures, show predominantly the formation of disilane $(\mathrm{m} / \mathrm{z}=62)$ and trisilane $(\mathrm{m} / \mathrm{z}=92)$, with no observation of the peaks from $\operatorname{Si}\left(\mathrm{ND}_{2}\right)_{3}{ }^{+}(\mathrm{m} / \mathrm{z}=82)$ and $\mathrm{Si}\left(\mathrm{ND}_{2}\right)_{4}{ }^{+}(\mathrm{m} / \mathrm{z}=100)$. For the $23: 1$ 
$\mathrm{ND}_{3}: \mathrm{SiH}_{4}$ mixture, a strong and broad peak centered at $\mathrm{m} / \mathrm{z}=70$ was observed in the mass spectra recorded at different temperatures. This peak is overloaded in Figure $3 b$ ) and is always accompanied by relatively weaker but broad peaks at $\mathrm{m} / \mathrm{z}=28$ and 56 . The intensities of these peaks decay very quickly with increasing filament-on time for each temperature run. They could be from the $\mathrm{Si} / \mathrm{Si}_{2}$ or $\mathrm{Si}_{\mathrm{x}} \mathrm{N}_{\mathrm{y}}$ species, but their true identities and how they are formed need a more detailed investigation. As shown in Figures 3c) and 3d), the formation of tetraaminosilane, represented by the peaks at $\mathrm{m} / \mathrm{z}=82$ and 100, takes over for the mixtures with higher $\mathrm{NH}_{3}$ content (the $49: 1$ and $100: 1 \mathrm{ND}_{3}: \mathrm{SiH}_{4}$ ). The change in the reaction chemistry from the formation of disilane and trisilane to that of the aminosilane with increasing $\mathrm{NH}_{3}$ content in the mixture is further confirmed.

Additional support for the formation of tetraaminosilane in the HWCVD processes with $\mathrm{NH}_{3}-\mathrm{SiH}_{4}$ mixtures was gained by examining the behavior of the peaks at $\mathrm{m} / \mathrm{z}=62$, 92 (using $\mathrm{NH}_{3}$ ) and at $\mathrm{m} / \mathrm{z}=82,100$ (using $\mathrm{ND}_{3}$ ) as a function of the filament temperature. As shown in Figure 4, the peak intensities at $\mathrm{m} / \mathrm{z}=62$ and 92 from the $1: 1 \mathrm{NH}_{3}: \mathrm{SiH}_{4}$ mixture decreased with increasing filament temperature.

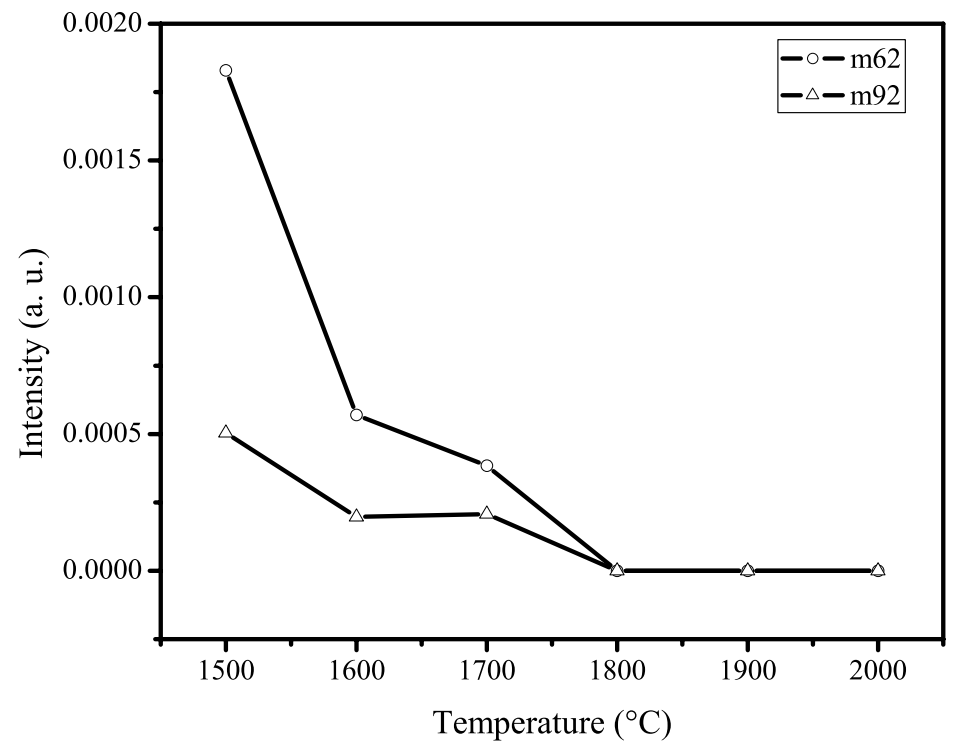

Figure 4. The distribution of the peak intensities at $\mathrm{m} / \mathrm{z}=62$ and $\mathrm{m} / \mathrm{z}=92$ for the $1: 1 \mathrm{NH}_{3}$ : $\mathrm{SiH}_{4}$ mixture versus the filament temperature.

For the $100: 1 \mathrm{NH}_{3}: \mathrm{SiH}_{4}$ mixture, the intensity of the peak at $\mathrm{m} / \mathrm{z}=92$ first increased with temperature and reached a maximum at $1800{ }^{\circ} \mathrm{C}$. This is shown in Figure 5a). The intensity distribution for the peak at $\mathrm{m} / \mathrm{z}=62$ from the $100: 1 \mathrm{NH}_{3}: \mathrm{SiH}_{4}$ mixture is too weak to be plotted. The difference in the intensity distribution with filament temperature for the same peak at $\mathrm{m} / \mathrm{z}=$ 92 with different mixtures is due to the fact that it is from different origins. As has been 
discussed before, this peak from the $1: 1 \mathrm{NH}_{3}: \mathrm{SiH}_{4}$ mixture corresponds to trisilane, characteristic of silane chemistry, and the same mass peak from the $100: 1 \mathrm{NH}_{3}: \mathrm{SiH}_{4}$ mixture is predominantly from tetraaminosilane. Not surprisingly, as illustrated in Figure 5b), the temperature distribution for the peak at $\mathrm{m} / \mathrm{z}=100$ representing $\mathrm{Si}\left(\mathrm{ND}_{2}\right)_{4}{ }^{+}$from the $100: 1 \mathrm{ND}_{3}$ : $\mathrm{SiH}_{4}$ mixture shows similar behavior to that of the one at $\mathrm{m} / \mathrm{z}=92\left(\mathrm{Si}\left(\mathrm{NH}_{2}\right)_{4}{ }^{+}\right)$from the $100: 1$ $\mathrm{NH}_{3}: \mathrm{SiH}_{4}$ mixture. The existence of an optimum filament temperature for the formation of aminosilane is a result of the balance for the opposite behavior of the $\mathrm{NH}_{2}$ and $\mathrm{SiH}_{3}$ radicals, the two initial reactants, with filament temperature.

As shown before, the intensities of disilane and trisilane formed from $\mathrm{SiH}_{3}$ radicals showed a decrease with increasing filament temperature. The decrease of the $\mathrm{SiH}_{3}{ }^{+}$signal intensity with temperature has also been demonstrated by Tange et al. ${ }^{27}$ Umemoto et al. ${ }^{29}$ has shown that the $\mathrm{NH}_{2}$ radical intensity grows with filament temperature, and this is confirmed in our previous work with $50 \% \mathrm{NH}_{3}$ in the HWCVD reactor. ${ }^{14}$
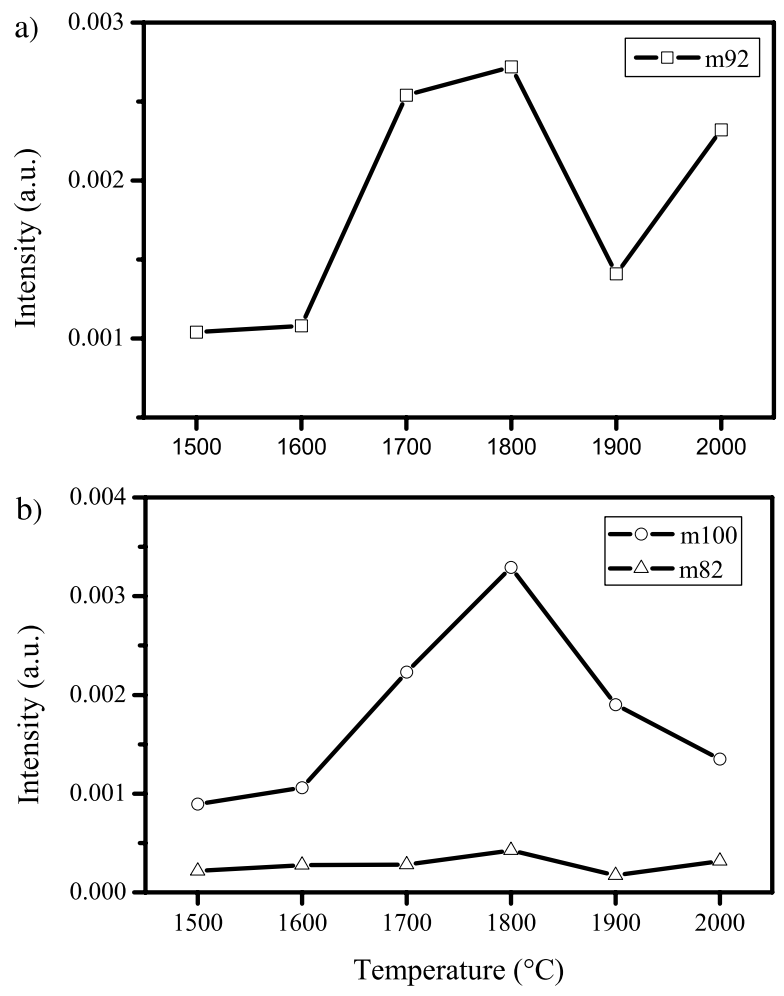

Figure 5. The distribution of the peak intensities at (a) $\mathrm{m} / \mathrm{z}=92$ for the $100: 1 \mathrm{NH}_{3}: \mathrm{SiH}_{4}$ mixture; and (b) $\mathrm{m} / \mathrm{z}=82$ and 100 for the $100: 1 \mathrm{ND}_{3}: \mathrm{SiH}_{4}$ mixture versus the filament temperature 
An important question to be addressed in studying the gas-phase reaction chemistry of $\mathrm{SiH}_{4}$ $\mathrm{NH}_{3}$ mixtures in HWCVD is whether or not there is any cross-talk between $\mathrm{SiH}_{4}$ and $\mathrm{NH}_{3}$ molecules and their respective filament decomposition products during the formation of disilane and trisilane. Based on the fact that these two species are observed even when $\mathrm{NH}_{3}$ is absent, it is believed that the $\mathrm{H}$ atoms in disilane and trisilane originate from $\mathrm{SiH}_{4}$ molecule itself. If this is true, then even with $\mathrm{ND}_{3}$ replacing $\mathrm{NH}_{3}$ in the source gas mixtures, the disilane and trisilane species should still appear at $\mathrm{m} / \mathrm{z}=62$ and 92 , rather than be shifted to $\mathrm{m} / \mathrm{z}=62+\mathrm{m}(\mathrm{m}=0-6)$ and $92+n(n=0-8)$, respectively. Examination of the mass spectra of $1: 1$ and $23: 1 \mathrm{ND}_{3}$ : $\mathrm{SiH}_{4}$ mixture in Figure 3 shows that this is indeed the case. This clearly demonstrates that the disilane and trisilane production from silane or silane-ammonia mixtures occurs without interference or interaction with ammonia.

\section{Conclusions}

Gas-phase reaction products from the HWCVD reactor with $\mathrm{SiH}_{4}-\mathrm{NH}_{3}$ mixtures of various partial pressure ratios ranging from $1: 1$ to $200: 1$ for $\mathrm{NH}_{3}: \mathrm{SiH}_{4}$ have been examined using VUV SPI / TOF mass spectrometry. When the two components are present in equal amount, the formation of disilane and trisilane dominates. The two mass peaks appear in approximately the same amounts when compared with those for the $1 \% \mathrm{SiH}_{4}$ in $\mathrm{He}$ sample. Increasing the amount of ammonia in the mixture causes a shift in the reaction pathway from disilane and trisilane production toward aminosilane formation. When $\mathrm{NH}_{3}$ is present in a 49 : 1 ratio to $\mathrm{SiH}_{4}$, aminosilane dominates in the reaction products. The identities of the $\mathrm{Si}\left(\mathrm{NH}_{2}\right)_{4}{ }^{+}$and $\mathrm{Si}\left(\mathrm{NH}_{2}\right)_{3}{ }^{+}$ were confirmed by examining the products from mixtures with the isotopmer $\mathrm{ND}_{3}$ replacing the $\mathrm{NH}_{3}$ component. Using isotopically labeled $\mathrm{ND}_{3}$, it has also been shown that the H-atoms in the aminosilane species come solely from $\mathrm{NH}_{3}$. This is consistent with the formation mechanism of aminosilanes by way of stepwise amination reactions between $\mathrm{SiH}_{3}$ radicals originating from $\mathrm{SiH}_{4}$ decomposition and $\mathrm{NH}_{2}$ radicals from $\mathrm{NH}_{3}$ decomposition. No interference or interaction with ammonia is found in the formation of disilane and trisilane.

The production of sufficient amount of $\mathrm{NH}_{2}$ ( or $\mathrm{ND}_{2}$ ) radicals plays a key role in the competition between the two pathways. Insufficient $\mathrm{NH}_{2}$ densities will result in the formation of disilane and trisilane species, since the $\mathrm{SiH}_{3}$ radicals produced from $\mathrm{SiH}_{4}$ decomposition will react with each other, rather than with the $\mathrm{NH}_{2}$. High $\mathrm{NH}_{2}$ densities favor aminosilane formation. The presence of $\mathrm{SiH}_{4}$ suppresses $\mathrm{NH}_{3}$ decomposition, and the suppression extent is reduced when the $\mathrm{NH}_{3}$ content is high. Therefore, it is necessary to have a large excess of $\mathrm{NH}_{3}$ in the gas mixture to ensure good decomposition efficiency and $\mathrm{NH}_{2}$ production to promote aminosilane formation. The optimum filament temperature for aminosilane formation is found to be 1700 to $1800{ }^{\circ} \mathrm{C}$, whereas low filament temperatures favor the formation of disilane and trisilane. It should be possible to select experimental conditions that maximize formation of 
either aminosilanes or di-/tri-silane species through adjustment of the source gas composition and the filament temperature.

\section{Acknowledgements}

This work is funded by the National Sciences and Engineering Research Council of Canada (NSERC) and the University of Calgary.

\section{References}

1. Masuda, A.; Umemoto, H.; Matsumura, H. Thin Solid Films 2006, 501, 149.

2. van den Oever, P. J.; Van Helden, J. H.; van Hemmen, J. L.; Engeln, R.; Schram, D. C.; van de Sanden, M. C. M.; Kessels, W. M. M. J. Appl. Phys. 2006, 100, 093303.

3. Bailey, R. S.; Kapoor, V. J. J. Vac. Sic. Technol. 1982, 20, 484.

4. Smith, D. L.; Alimonda, A. S.; Chen, C-C.; Ready, S. E.; Wacker, B. J. Electrochem. Soc. 1990, 137, 614.

5. Hicks, S. E.; Gibson, R. A. G. Plasma Chem. Plasma Processing 1991, 11, 455.

6. Murley, D. T.; Gibson, R. A. G.; Dunnett, B.; Goodyear, A.; French, I. D. J. Non-Cryst. Solids. 1995, 187, 324.

7. Beach, D. B.; Jasinski, J. M. J. Phys. Chem. 1990, 94, 3019.

8. Wu, C-H. J. Phys. Chem. 1987, 91, 5054.

9. Yoshimoto, M.; Takubo, K.; Ohtsuki, T.; Komoda, M.; Matsunami, H. J. Electrochem. Soc. 1995, 142, 1976.

10. Wang, Q.; Ward, S.; Gedvilas, L.; Keyes, B.; Sanchez, E.; Wang, S. Appl. Phys. Lett. 2004, $84,338$.

11. Umemoto, H.; Morimoto, T.; Yamawaki, M.; Masuda, Y.; Masuda, A.; Matsumura, H. Thin Solid Films 2003, 430, 24.

12. Holt, J. K.; Mason, M. S.; Goodwin, D. G.; Atwater, H. A. In Amorphous and heterogeneous silicon-base films, Material Research Society Symposium Proceedings, Vol. 715. Abelson, J. R.; Boyce, J. B.; Cohen, J. D.; Matsumura, H.; Robertson, J., Eds.; Warrendale, 2002, p A 10.2 .

13. Stannowski, B.; Rath, J. K.; Schropp, R. E. I. J. Appl. Phys. 2003, 93, 2618.

14. Eustergerling, B.; Hedén, M.; Shi, Y. J. J. Am. Soc. Mass Spectrom. 2007, 18, 1950.

15. Shi, Y. J.; Eustergerling, B. D.; Li, X. M. Thin Solid Films 2008, 516, 506.

16. Hu, S-W.; Wang, Y.; Wang, X-Y.; Chu, T-W.; Liu, X-Q. J. Phys. Chem. A. 2003, 107, 9189.

17. Koseki, S.; Ishitani, A. J. Appl. Phys. 1992, 72, 5808.

18. O’Neal, H. E.; Ring, M. A.; Martin, J. G.; Navio, M. T. J. Phys. Chem. A. 1998, 102, 8493. 
19. Kushner, M. J. J. Appl. Phys. 1992, 71, 4173.

20. Shi, Y. J.; Lo, B.; Tong, L.; Li, X.; Eustergerling, B. D.; Sorensen, T. S. J. Mass Spectrom. $\mathbf{2 0 0 7}, 42,575$.

21. Li, X. M.; Eustergerling, B. D.; Shi, Y. J. Int. J. Mass Spectrom. 2007, 263, 233.

22. Gallagher, A. Thin Solid Films 2001, 395, 25.

23. Duan, H. L.; Zaharias, G. A.; Bent, S. F. Curr. Opin. Solid State Mat. Sci. 2002, 6, 471.

24. Van Veenendaal, P. A. T. T.; Schropp, R. E. I. Curr. Opin. Solid State Mat. Sci. 2002, 6, 465.

25. Holt, J. K.; Swiatek, M.; Goodwin, D. G.; Muller, R. P.; Goddard III, W. A.; Atwater, H. A. Thin Solid Films 2001, 395, 29.

26. Duan H. L.; Zaharias, G. A.; Bent, S. F. Appl. Phys. Lett. 2001, 78, 1784.

27. Tange, S.; Inoue, K.; Tonokura, K.; Koshi, M. Thin Solid Films, 2001, 395, 42.

28. Nakamura, S.; Koshi, M. Thin Solid Films 2006, 501, 26.

29. Umemoto, H.; Ohara, K.; Morita, D.; Morimoto, T.; Yamawaki, M.; Masuda, A.; Matsumura, H. Jpn. J. Appl. Phys. 2003, 42, 5315. 